\title{
Assessment of Genotoxic Effects of Pendimethalin in Chinese Hamster Over Cells by the Single Cell Gel Electrophoresis (Comet) Assay
}

\author{
Pendimetalinin Genotoksik Etkilerinin Çin Hamster Over Hücrelerinde Tek \\ Hücre Jel Elektroforez (Comet) Yöntemiyle Değerlendirilmesi
}

Nazlı DEMIR, Sevtap AYDIN, Ülkü ÜNDEĞER BUCURGAT*

Hacettepe University, Faculty of Pharmacy, Department of Pharmaceutical Toxicology, Ankara, Turkey

\begin{abstract}
Objectives: Pendimethalin ( $N$-(1-ethylpropyl)-3,4-dimethyl-2,6-dinitrobenzeneamine) is a dinitroaniline herbicide compound which selectively controls weeds. It is a cell division and growth inhibitor. It descends plants in a short time after seedling. It is a soil and water pollutant due to the widespread use of formulations in Turkey and around the world. Pendimethalin is manufactured in and imported by Turkey. Pendimethalin is a slightly toxic compound that is classified in toxicity class 3 by the United States Environmental Protection Agency (USEPA). Even though it is classified as group C (human possible carcinogen) compound by the USEPA, there are limited number of studies about its genotoxic effects. The aim of this study was to evaluate in vitro genotoxic effects of different concentrations of pendimethalin in Chinese hamster over (CHO) cells by the single cell gel electrophoresis (comet) assay.

Materials and Methods: The cells are incubated with 1, 10,100, 1000 and $10000 \mu \mathrm{M}$ concentrations of pendimethalin for 30 min at $37^{\circ} \mathrm{C}$ and $\mathrm{DNA}$ damage was compared with $\mathrm{CHO}$ cells untreated with pendimethalin. $50 \mu \mathrm{M}$ hydrogen peroxide was used as positive control.

Results: No significant cytotoxic effects were observed within the concentration ranges studied. The DNA damage in $\mathrm{CHO}$ cells was significantly increased in the pendimethalin concentrations of $1,100,1000$ and $10000 \mu \mathrm{M}$, however, a significant decrease was observed in $10 \mu \mathrm{M}$ pendimethalin concentration.

Conclusion: Our results show that $1-10000 \mu \mathrm{M}$ concentrations of pendimethalin induce DNA damage in $\mathrm{CHO}$ cells, which was assessed by comet assay.
\end{abstract}

Key words: Pendimethalin, herbicide, DNA damage, comet assay, CHO cells

ÖZ

Amaç: Pendimetalin (N-(1-etilpropil)-3,4-dimetil-2,6-dinitrobenzenamin) seçici bitki kontrolü yapan dinitroanilin türevi bir herbisit bileşiktir. Hücre bölünmesi ve büyümesi engelleyicisidir. Bitkilerin filizlenme aşamasından kısa süre sonra ölmelerine neden olur. Türkiye'de ve dünyada formülasyonlarının yaygın kullanımı nedeniyle toprak ve su kirleticisidir. Pendimetalin Türkiye'de üretilmekte ve ithal edilmektedir. Pendimetalin az toksik bir bileşiktir ve Amerika Birleşik Devletleri Çevre Koruma Ajansı'na (USEPA) göre toksisite sınıfı 3'tür. USEPA tarafından grup C (insanda olası kanserojen) olarak sınıflandırıımasına rağmen genotoksik etkileri sınırlı sayıda çalışılmıştır. Bu çalışmanın amacı, farklı konsantrasyonlardaki pendimetalinin Çin hamster over (CHO) hücrelerindeki in vitro genotoksik etkilerini tek hücre jel eletroforez (comet) yöntemiyle değerlendirmektir. Gereç ve Yöntemler: Hücreler 1, 100, 1000 ve $10000 \mu \mathrm{M}$ konsantrasyonlardaki pendimetalin ile $37^{\circ} \mathrm{C}^{\prime}$ de 0.5 saat inkübe edilmiş ve DNA hasarı pendimetalin uygulanmayan $\mathrm{CHO}$ hücreleriyle karşılaştırılmıştır. $50 \mu \mathrm{M}$ hidrojen peroksit pozitif kontrol olarak kullanılmıştır.

Bulgular: Çalışılan konsantrasyon aralığında önemli sitotoksik etki gözlenmemiștir. CHO hücrelerindeki DNA hasarı 1, 100,1000 ve $10000 \mu \mathrm{M}$ konsantrasyonlarda önemli derecede artarken, $10 \mu \mathrm{M}$ pendimetalin DNA hasarını önemli derecede azaltmıştır.

Sonuç: Sonuçlarımız, 1-10000 $\mu \mathrm{M}$ konsantrasyon aralığındaki pendimetalinin CHO hücrelerinde comet yöntemiyle değerlendirilebilen DNA hasarını indüklediğini ortaya koymaktadır.

Anahtar kelimeler: Pendimetalin, herbisit, DNA hasarı, comet yöntemi, CHO hücreleri

*Correspondence: E-mail: uundeger@hacettepe.edu.tr, Phone: +90 3123092958

ORCID ID: orcid.org/0000-0002-6692-0366

Received: 14.07.2016, Accepted: 06.10.2016

-Turk J Pharm Sci, Published by Galenos Publishing House. 


\section{INTRODUCTION}

Pendimethalin (PM), whose chemical name is ( $N$-(1-ethylpropyl)3,4-dimethyl-2,6-dinitrobenzeneamine), is a dinitroaniline herbicide. It is an inhibitor of cell division and cell elongation which selectively terminates weeds. This pre- and early postemergence herbicide is used to control broadleaf weeds and grassy weed species in cabbage, carrots, celery, cereals, citrus, corn, cotton, garlic, lettuce, onions, peanuts, peas, pome fruits, potatoes, radish, rice, sorghum, soybeans, tomatoes, tobacco and stone fruits. Moreover, it is also used in nonagricultural areas, residential lawns and ornamentals. PM is a widely used herbicide in different formulations; so that, it can be detected as a contaminant in surface and ground water, in soil and air with increasing amount.1.2 It may disperse through leaching, drift, evaporation and runoff after application to soil. It is also degraded by photo- and bio-degradation or volatilization., ${ }^{3,4} \mathrm{PM}$ is classified as a slightly toxic compound and also classified in group $\mathrm{C}$ carcinogen (human possible carcinogen) by Environmental Protection Agency. ${ }^{5}$ In spite of this classification only a few works have been published on the genotoxic effects of PM. PM induces cytotoxicity in rat hepatocytes evaluated by altered mitochondrial respiration. ${ }^{6}$ It also shows cytotoxic effect in FRTL 5 (rat thyroid) ${ }^{7}$ and Chinese hamster over (CHO) cell line. ${ }^{8}$ Dimitrov et al. ${ }^{9}$ (2006) has shown that PM significantly increased the chromosomal aberrations at $489 \mathrm{mg} / \mathrm{kg}$ dose in mouse bone marrow. In addition, it induced the micronucleus frequency in plant cell and mouse bone marrow polychromatic erythrocytes. PM achieved, concentration dependent (0.1-100 $\mathrm{mM}$ ) induction in DNA damage evaluated by Comet assay in $\mathrm{CHO}$ cells. ${ }^{8}$ PM decreased the root bundle length and increased the mitotic index and the percentage of chromosome aberrations dose dependently in maize and onion..$^{10}$ It has been reported to be a contaminant for the environment and found highly toxic for fish and aquatic invertebrates." PM exposure has been correlated with an increased incidence of cancer. ${ }^{12,13}$ On the other hand, Hou et al. ${ }^{14}$ detected no association of exposure of PM during lifetime either with specific cancer sites or with overall cancer incidence among pesticide applicators in North Carolina and lowa.

The Alkaline Single-cell Gel Electrophoresis technique or comet assay is a versatile tool for assessing DNA damage. Comet assay measures strand breaks, incomplete excision repair events, alkaline labile sites and cross-linking in individual cells. It has been shown to be a method commonly used for measuring the genetic damage induced in vitro by different genotoxic agents and also for determining DNA repair under a variety of experimental conditions.15,16 This assay is also widely used for the evaluation of DNA damage in studies to characterize DNA lesions with and without the addition of the repair enzymes such as formamidopyrimidine $\mathrm{N}$-glycosylase (FPG). FPG is a base excision repair enzyme, it initiates the repair of oxidized bases by recognizing, excising them and cutting the sugar-phosphate backbone of the DNA molecule. At the location of oxidized DNA bases, additional DNA strand breaks occurs and these leads to DNA migration. The determination of FPG-sensitive DNA lesions indicates the appearence of oxidized purine bases. ${ }^{17-19}$
In this study, the genotoxic potentials of dinitroaniline herbicide $\mathrm{PM}$ is investigated at different concentrations in $\mathrm{CHO}$ cells by using the comet assay with and without the addition of the repair enzyme FPG.

\section{EXPERIMENTAL}

\section{Chemicals}

The cells were purchased from Republic of Turkey, Ministry of Food, Agriculture and Livestock. The chemicals used in the experiments were purchased from the following suppliers: Low melting agarose (LMA) and normal melting agarose (NMA) (respectively) from Boehringer Manheim (Manheim, Germany); sodium hydroxide $(\mathrm{NaOH})$ and sodium chloride $(\mathrm{NaCl})$ from Merck Chemicals (Darmstadt, Germany); RPMI 1640 medium, fetal calf serum (FCS), trypsin-EDTA, penicillin-streptomycin, dimethylsulfoxide (DMSO), hydrogen peroxide $\left(\mathrm{H}_{2} \mathrm{O}_{2}\right)$, ethidium bromide, Triton X-100, phosphate-buffered saline tablets, ethylenediamine tetraacetic acid disodium salt dihydrate (EDTA), $\mathrm{N}$-lauroyl sarcosinate, Tris $\mathrm{HCl}$, bovine serum albumin (BSA) and FPG enzyme from Sigma-Aldrich (St. Louis, MO, USA); olive oil from Egaş (Ankara, Turkey).

\section{Cell culture}

$\mathrm{CHO}$ cells were seeded in $75 \mathrm{~cm}^{2}$ flasks in $20 \mathrm{~mL}$ RPMI 1640 medium (phenol red-free, with L-glutamine and $10 \%$ FCS) for $24 \mathrm{~h}$ in a $5 \% \mathrm{CO}_{2}$ atmosphere at $37^{\circ} \mathrm{C}$.

\section{Treatment of cells}

$\mathrm{CHO}$ cells were treated for 30 min with 1, 10, 100, 1000 and $10000 \mathrm{mM}$ concentrations of PM which dissolved in $0.5 \%$ DMSO and $0.02 \%$ olive oil mixture. $0.5 \%$ DMSO and $0.02 \%$ olive oil mixture were used as (-) controls. As positive control, to create oxidative DNA damage, $50 \mathrm{mM} \mathrm{H} \mathrm{H}_{2}$ solution was applied to cells for 5 min on ice, then $\mathrm{H}_{2} \mathrm{O}_{2}$ solution was removed. $\mathrm{CHO}$ cells were disaggregated with trypsin EDTA and resuspendated in $10 \%$ FCS containing medium. Cells were centrifugated for 3 min at $3000 \mathrm{rpm}$, the supernatant was removed.

\section{Evaluation of cell viability}

Trypan blue dye exclusion technique was performed for evaluation of cell viability. ${ }^{19}$

\section{Comet assay}

The basic alkaline comet assay of Singh et al. ${ }^{20}$, as later mentioned by Collins et al. ${ }^{21}$, was performed in the standard version and post-treatment with FPG protein to evaluate oxidative DNA damage was used as described in.16,22,23 The precipitated cells were resuspended and mixed with $80 \mathrm{~mL}$ of LMA for embedding on slides which were covered with $1 \%$ NMA. Approximately 25.000 cells mixed with $80 \mathrm{~mL}$ of $1 \%$ LMA were rapidly pipetted onto this slide as the second layer. Slides were covered with cover slips, then kept on an ice-cold flat tray for $5 \mathrm{~min}$ to solidify. Cover slips were removed and slides were immersed in cold lysing solution $(2.5 \mathrm{M} \mathrm{NaCl}, 100$ $\mathrm{mM} \mathrm{Na}{ }_{2}$ EDTA, $10 \mathrm{mM}$ Tris, $1 \%$ sodium laurylsarcosinate, $\mathrm{pH}$ 10) with $1.5 \%$ Triton $\mathrm{X}-100$ and $10 \%$ DMSO was added just before use, for a minimum period of $1 \mathrm{~h}$ at $4^{\circ} \mathrm{C} . \mathrm{H}_{2} \mathrm{O}_{2}$ treated positive 
control cells were immersed in a seperate cold lysing solution. Following lysis, slides were washed in enzyme buffer (20 mM Tris $\mathrm{HCl}, 1 \mathrm{mM} \mathrm{Na}$ EDTA, $100 \mathrm{mM} \mathrm{NaCl}, 0.5 \mathrm{mg} \mathrm{BSA} / \mathrm{mL}, \mathrm{pH}$ 7.5) at $4^{\circ} \mathrm{C}$, four times for $5 \mathrm{~min}, 20 \mathrm{~min}$ in total. Slides were covered with $200 \mathrm{~mL}$ of FPG protein $(1 \mathrm{mg} / \mathrm{mL}$ ) in enzyme buffer for detection of FPG-sensitive DNA lesions, and incubated for $30 \mathrm{~min}$ at $37^{\circ} \mathrm{C}$, then cover slips were removed. Slides were placed in a horizontal gel electrophoresis tank. The tank was filled with fresh electrophoresis solution (1 mM NaEDTA, and $300 \mathrm{mM} \mathrm{NaOH}, \mathrm{pH}$ 13). Slides were left in the electrophoresis solution for 20 min to allow the unwinding of the DNA and expression of alkaline labile damage before electrophoresis. Electrophoresis was conducted at a low temperature for $20 \mathrm{~min}$ using 25 volts and adjusting the current to 300 miliamperes. All of the steps were carried out under dimmed light to prevent the occurrence of additional DNA damage. The slides were washed with neutralysing buffer, three times after electrophoresis. Following the slides were washed in distilled water, 50\%, 75\% and $99 \%$ ethanol (for $5 \mathrm{~min}$ each), they were allowed to dry at room temperature. $30 \mathrm{~mL}$ of EtBr solution $(20 \mathrm{mg} / \mathrm{mL}$ ) was added to each slide for staining. The slides were investigated thoroughly by the use of a Leica fluorescence microscope (Leica, Wetzlar, Germany) with 400-fold magnification. The tail length, intensity, moment and migration of 'comets' were measured with a computerised image analysis system-comet Assay III Perceptive Instruments (Suffolk, England) for randomly selected 100 cells, i.e. 50 cells from each of two replicate slides from each sample. And the mean value of these parameters was used for the evaluation of the DNA damage by repeating the experiments for three times.

\section{Statistical analysis}

The statistical analysis was performed by SPSS for Windows 11.5 software (SPSS Software, Chicago, IL, USA). The results from the DMSO+olive oil-treated negative control, $\mathrm{H}_{2} \mathrm{O}_{2}$ treated positive control, and test groups treated with different concentrations of PM were statistically compared by the use of one-way ANOVA and the post hoc analysis of the group differences was evaluated by the least significant difference test and finally the results were expressed as means \pm standard error of the mean (SEM).

\section{RESULTS}

CHO cells are exposed to PM (1-10000 mM) for 30 min. Cell viability was greater than $90 \%$. DNA damage is determined with comet assay in this study. In comet assay, the amount of DNA breakage in a cell is estimated from the migration extent (tail length) of the genetic material in the direction of anode. ${ }^{20}$ Also, the DNA percentage in the tail (tail intensity) has been shown to be proportional to the frequency of DNA strand breaks. ${ }^{24}$ Tail moment is a simple identifier calculated by the computerized image analysis system considering both the migration tail length as well as the fraction of DNA migrated in the tail. ${ }^{25}$ The DNA damage in $\mathrm{CHO}$ cells following in vitro 30 min treatment with 1-10000 mM concentrations of $\mathrm{PM}$ and post treatment with $50 \mathrm{mM} \mathrm{H}_{2} \mathrm{O}_{2}$ and $50 \mathrm{mM} \mathrm{H}_{2} \mathrm{O}_{2}+\mathrm{FPG}$ protein after PM treatment are shown in Table 1, 2 and Figure 1a-d. Results are given as

Table 1. DNA damage as tail length and tail intensity in $\mathrm{CHO}$ cells treated with pendimetalin

\begin{tabular}{|c|c|c|c|c|}
\hline & & PM treated $\mathrm{CHO}$ cells & $\mathrm{PM}+\mathrm{H}_{2} \mathrm{O}_{2}$ treated $\mathrm{CHO}$ cells & $\mathrm{PM}+\mathrm{H}_{2} \mathrm{O}_{2}+\mathrm{FPG}$ treated $\mathrm{CHO}$ cells \\
\hline & Comet parameter & Tail length & & \\
\hline 1 & (-) Control & $17.25 \pm 0.35$ & $28.17 \pm 0.45^{\star \star *}$ & $60.56 \pm 0.88^{\# \# \#}$ \\
\hline 2 & $1 \mu \mathrm{M}$ PM & $18.41 \pm 0.40^{+}$ & $32.23 \pm 0.41^{* * *}$ & $61.55 \pm 0.72^{\# \# \#}$ \\
\hline 3 & $10 \mu \mathrm{M} P M$ & $15.66 \pm 0.36^{++}$ & $31.39 \pm 0.35^{* * *}$ & $71.21 \pm 0.62^{\# \# \#}$ \\
\hline 4 & $100 \mu \mathrm{M}$ PM & $19.93 \pm 0.42^{+++}$ & $29.88 \pm 0.32^{* * *}$ & $66.43 \pm 0.61^{\# \# \#}$ \\
\hline 5 & $1000 \mu \mathrm{M}$ PM & $19.13 \pm 0.39^{++}$ & $29.18 \pm 0.37^{\star \star \star}$ & $65.49 \pm 0.57^{\# \# \#}$ \\
\hline \multirow[t]{2}{*}{6} & $10000 \mu \mathrm{M}$ PM & $20.65 \pm 0.50^{+++}$ & $34.64 \pm 0.36^{* \star *}$ & $65.60 \pm 0.59^{\# \# \#}$ \\
\hline & & Tail intensity & & \\
\hline 1 & (-) Control & $7.89 \pm 0.54$ & $15.23 \pm 0.99^{* * *}$ & $64.46 \pm 1.41^{\# \# \#}$ \\
\hline 2 & $1 \mu \mathrm{M}$ PM & $7.46 \pm 0.62$ & $24.34 \pm 1.53^{* \star *}$ & $56.79 \pm 1.32^{\# \# \#}$ \\
\hline 3 & $10 \mu \mathrm{M}$ PM & $6.06 \pm 0.54^{+}$ & $34.81 \pm 1.37^{\star \star *}$ & $62.28 \pm 1.32^{\# \# \#}$ \\
\hline 4 & $100 \mu \mathrm{M}$ PM & $8.40 \pm 0.65$ & $38.85 \pm 1.32^{* * *}$ & $62.52 \pm 1.33^{\# \# \#}$ \\
\hline 5 & $1000 \mu \mathrm{M}$ PM & $8.48 \pm 0.62$ & $33.33 \pm 1.32^{* * *}$ & $59.01 \pm 1.25^{\# \# \#}$ \\
\hline 6 & $10000 \mu \mathrm{M}$ PM & $9.83 \pm 0.86$ & $51.03 \pm 1.36^{* * *}$ & $57.75 \pm 1.33^{\# \# \#}$ \\
\hline
\end{tabular}

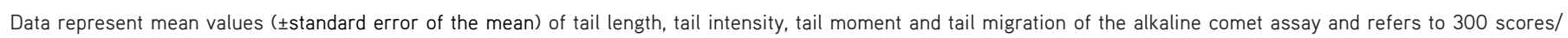
concentration (100 scores/experiment, three experiments)

PM: Pendimetalin, CHO: Chinese hamster over, ${ }^{+} \mathrm{p}<0.05,{ }^{++} \mathrm{p}<0.01,{ }^{+++} \mathrm{p}<0.001$ significance of DNA damage in PM treated $\mathrm{CHO}$ cells compared with $\mathrm{DMSO}(0.5 \%)+0$ live oil (0.02\%)

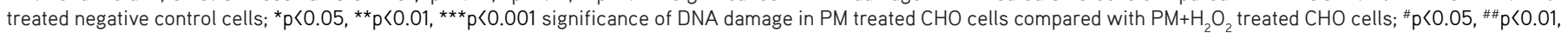
$\# \#$ $\mathrm{p}<0.001$ significance of DNA damage in $\mathrm{PM}+\mathrm{H}_{2} \mathrm{O}_{2}$ treated $\mathrm{CHO}$ cells with $\mathrm{PM}+\mathrm{H}_{2} \mathrm{O}_{2}+\mathrm{FPG}$ treated $\mathrm{CHO}$ cells 

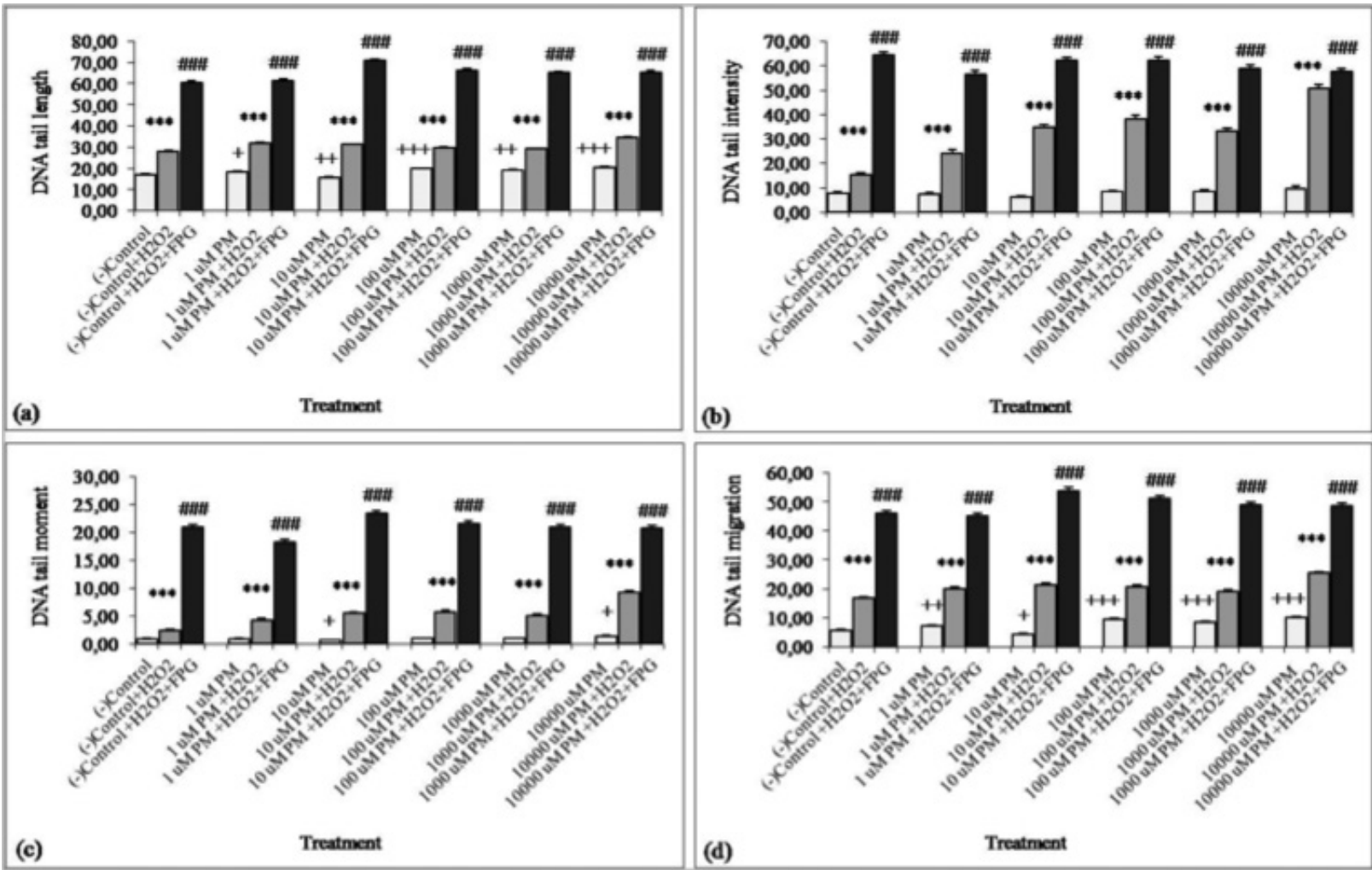

Figure 1. Genotoxic effects of pendimethalin for 30 min with or without Fpg in $\mathrm{CHO}$ cells, a) DNA damage was expressed as DNA tail length, b) DNA tail intensity (\% DNA tail), c) DNA tail moment and d) DNA tail migration, results were given as the mean \pm standard deviation

PM: Pendimethalin, FPG: Formamidopyrimidine $N$-glycosylase, ${ }^{+} p<0.05,{ }^{+*} p<0.01,{ }^{++} p<0.001, \mathrm{PM}$ treatment compared to negative control [DMSO $(0.5 \%)+o$ olive oil $\left.(0.2 \%)\right]$, ${ }^{*} p<0.05$,

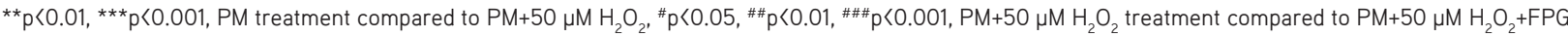

Table 2. DNA damage as tail moment and tail migration in $\mathrm{CHO}$ cells treated with pendimetalin

$\mathrm{PM}$ treated $\mathrm{CHO}$ cells

$\mathrm{PM}+\mathrm{H}_{2} \mathrm{O}_{2}$ treated $\mathrm{CHO}$ cells

$\mathrm{PM}+\mathrm{H}_{2} \mathrm{O}_{2}+\mathrm{FPG}$ treated $\mathrm{CHO}$ cells

\begin{tabular}{|c|c|c|c|c|}
\hline & Comet parameter & Tail moment & & \\
\hline 1 & (-) Control & $0.91 \pm 0.07$ & $2.40 \pm 0.18^{* *}$ & $20.85 \pm 0.53^{\# \# \#}$ \\
\hline 2 & $1 \mu \mathrm{M}$ PM & $0.90 \pm 0.08$ & $4.24 \pm 0.28^{* * *}$ & $18.22 \pm 0.47^{\# \# \#}$ \\
\hline 3 & $10 \mu \mathrm{M}$ PM & $0.64 \pm 0.06^{++}$ & $5.53 \pm 0.23^{* * *}$ & $23.34 \pm 0.54 \# \# \#$ \\
\hline 4 & $100 \mu \mathrm{M}$ PM & $0.98 \pm 0.08$ & $5.78 \pm 0.22^{* * *}$ & $21.49 \pm 0.53^{\# \# \#}$ \\
\hline 5 & $1000 \mu \mathrm{M}$ PM & $1.00 \pm 0.08$ & $5.11 \pm 0.24^{* * *}$ & $20.86 \pm 0.50^{\# \# \#}$ \\
\hline \multirow[t]{2}{*}{6} & $10000 \mu \mathrm{M}$ PM & $1.37 \pm 0.15^{++}$ & $9.20 \pm 0.27^{* * *}$ & $20.59 \pm 0.54^{\# \# \# ~}$ \\
\hline & & Tail migration & & \\
\hline 1 & (-) Control & $5.67 \pm 0.35$ & $16.75 \pm 0.46^{* * *}$ & $46.11 \pm 1.04^{\# \# \# ~}$ \\
\hline 2 & $1 \mu \mathrm{M} \mathrm{PM}$ & $7.24 \pm 0.39^{++}$ & $20.26 \pm 0.53^{* * *}$ & $45.33 \pm 0.92^{\# \# \#}$ \\
\hline 3 & $10 \mu \mathrm{M} P M$ & $4.36 \pm 0.35^{+}$ & $21.41 \pm 0.47^{\star \star \star}$ & $54.05 \pm 1.05^{\# \# \#}$ \\
\hline 4 & $100 \mu \mathrm{M}$ PM & $9.34 \pm 0.43^{+++}$ & $20.78 \pm 0.44^{\star * *}$ & $51.39 \pm 0.91^{\# \# \#}$ \\
\hline 5 & $1000 \mu \mathrm{M}$ PM & $8.57 \pm 0.39^{+++}$ & $19.29 \pm 0.49^{* * *}$ & $49.04 \pm 0.90^{\# \# \# ~}$ \\
\hline 6 & $10000 \mu \mathrm{M}$ PM & $10.04 \pm 0.52^{+++}$ & $25.42 \pm 0.53^{* * *}$ & $48.85 \pm 0.91^{\# \# \#}$ \\
\hline
\end{tabular}

Data represent mean values ( \pm standard error of the mean) of tail length, tail intensity, tail moment and tail migration of the alkaline comet assay and refers to 300 scores/ concentration (100 scores/experiment, three experiments)

PM: Pendimetalin, CHO: Chinese hamster over, ${ }^{+} p<0.05,{ }^{++} p<0.01,{ }^{++} p<0.001$ significance of DNA damage in PM treated CHO cells compared with DMSO (0.5\%) + olive oil (0.02\%)-treated negative control cells; ${ }^{*} \mathrm{p}<0.05,{ }^{* *} \mathrm{p}<0.01$, ${ }^{* * *} \mathrm{p}<0.001$ significance of DNA damage in $\mathrm{PM}$ treated $\mathrm{CHO}$ cells compared with $\mathrm{PM}+\mathrm{H}_{2} \mathrm{O}_{2}$ treated $\mathrm{CHO}$ cells; ${ }^{*} \mathrm{p}<0.05$,

\#\#<0.01, \#\#\# $<$ O0.001 significance of DNA damage in $\mathrm{PM}+\mathrm{H}_{2} \mathrm{O}_{2}$ treated $\mathrm{CHO}$ cells with $\mathrm{PM}+\mathrm{H}_{2} \mathrm{O}_{2}+\mathrm{FPG}$ treated $\mathrm{CHO}$ cells 
the mean values $( \pm$ SEM) of tail length, tail intensity, tail moment and tail migration.

According to the data obtained from three separate experiments, tail length and tail migration are significantly increased at all concentrations of the PM tested (1, 100, 1000 and $10000 \mu \mathrm{g} /$ $\mathrm{mL}$ ) when compared with those of untreated cells (Figure 1a, $1 d$, respectively). The tail length, tail intensity, tail moment and tail migration are significantly decreased at PM concentrations of $10 \mathrm{mM}$ above the control values (Figure 1a-d). Moreover, the tail moment is significantly increased at PM concentrations of $10000 \mathrm{mM}$ above the control values (Figure 1c).

Some inconsistencies among tail length, tail intensity, tail moment, tail migration and concentration are found (Figure 1ad). Significant tail length and tail moment increases are found in CHO cells with 1, 100, 1000 and 10000 mM PM concentrations (Figure 1a, 1c, respectively). On the other hand, significant tail length, tail intensity, tail moment and tail migration decreases are found in these cells with only $10 \mathrm{mM}$ PM concentration (Figure 1a-d). Generally, the genotoxic effects of the PM in $\mathrm{CHO}$ cells are appeared to be better reflected by tail length and tail migration than tail intensity and tail moment in this study. Post-treatment with $\mathrm{H}_{2} \mathrm{O}_{2}+\mathrm{FPG}$ protein reveals increases in all the investigated comet variables when compared to posttreatment with just $\mathrm{H}_{2} \mathrm{O}_{2}$, in previously 10,100 and $1000 \mathrm{mM}$ concentrations of PM treated $\mathrm{CHO}$ cells (Figure 1a-d). This finding shows that, DNA damage performed with 10, 100 and $1000 \mathrm{mM}$ concentrations of $\mathrm{PM}+\mathrm{H}_{2} \mathrm{O}_{2}$ treatment is an oxidative DNA damage which may be repaired by FPG protein.

\section{DISCUSSION}

DNA oxidative damage is a common type of damage of cells from reactive oxygen species (ROS) and it can lead to many different mutations and problems in DNA. Reactive oxygen species include hydrogen peroxide, superoxide anion radical, singlet oxygen, hydroxyl radical and nitric oxide. They are the consequence of normal body processes such as metabolism and also the consequence of interactions with toxic chemicals, certain drugs and radiation. ROS is not the only reason of oxidative DNA damage. Decreases in antioxidant defence and inhibition of repair of oxidative damage can also cause oxidation of DNA. ${ }^{26}$ It is clear that oxidative DNA damage may lead to mutations upon cells. Mutations are very important step in carcinogenesis, and so elevated levels of oxidative DNA damage plays a critical role in the initiation, promotion and progression stages of carcinogenesis. ${ }^{26,27}$ Oxidative DNA damage has also been associated with other diseases such as Alzheimer's disease, Huntington's disease, Parkinson's disease, hepatitis, atopic dermatitis, autoimmune diseases, atherosclerosis. ${ }^{26-28}$ ROS may also cause sperm disfunction and plays a significant role in male infertility. ${ }^{29}$ Additionally, it is suggested that the gradual accumulation of free-radical damage to biomolecules occurs aging. ${ }^{26,30}$

$\mathrm{PM}$ is widely used dinitroaniline herbicide in all continents of the world. On the other hand, scanty number of studies have been conducted on the genotoxic effects of PM. In this study, the
DNA damage in all variables examined in $\mathrm{CHO}$ cells at various concentrations with PM application for $30 \mathrm{~min}$, is created hormetic concentration-response ( $U$ shape concentrationresponse curve). Tail length and tail migration with $1 \mathrm{mM}$ concentration of PM significantly increases as compared to negative controls ( $p<0.05$ and $p<0.01$, respectively); while tail intensity and tail moment are decreased at $1 \mathrm{mM}$ concentration of PM, this decrease is statistically insignificant. However, DNA tail length ( $p<0.01$ ), tail intensity, tail moment and tail migration ( $p<0.05$ ) values of $\mathrm{CHO}$ cells at $10 \mathrm{mM}$ concentrations of $\mathrm{PM}$ application, significantly decreases compared to negative controls. In all the examined parameters, the DNA damage is increased with 100,1000 and $10000 \mathrm{mM}$ concentrations of PM applications when compared to negative controls. The increases in the DNA tail length and tail migration at three concentrations ( $p<0.001)$ and in the DNA tail moment for 1000 $\mathrm{mM}$ concentration $(\mathrm{p}<0.05)$ are statistically significant.

Our findings are in agreement with the results of the study conducted by Patel et al. ${ }^{8}$ This study is the only other comet study in the literature performed in various concentrations of $\mathrm{PM}$ applied $\mathrm{CHO}$ cells. Patel et al. ${ }^{8}$ were evaluated the cytotoxic effects of PM in $\mathrm{CHO}$ cells after application of PM for $3 \mathrm{~h}$ at $1,10,100,1000$ and $10000 \mathrm{mM}$ concentrations by MTT (3-(4,5-Dimethylthiazol-2-yl)-2,5-diphenyltetrazolium bromide) method, then they determined the DNA damage by comet assay. The results of this study show that, the $\mathrm{IC}_{50}$ value of $\mathrm{PM}$ is close to the $10000 \mathrm{mM}$. Moreover mitochondrial activity of $\mathrm{CHO}$ cells exposed to $10000 \mathrm{mM}$ concentrations of PM for 3 h, shows a decrease of $54 \%$ compared to controls. The $90 \%$ cell viability after $3 \mathrm{~h}$ of exposure of PM is determined in 10$100 \mathrm{mM}$. Patel et al. ${ }^{8}$ also report over $90 \%$ of cell survival by trypan blue staining method in $\mathrm{CHO}$ cells which are exposed to $0.01,0.1,1,10$ and $100 \mathrm{mM}$ concentrations of PM for $3 \mathrm{~h}$. The DNA damage is investigated by comet assay in terms of the arbitrary units, \% tail DNA and tail length. PM is found to cause a significant concentration dependent increase in DNA damage in the studied variables, at the concentrations of 0.1 to $100 \mathrm{mM}$ (p<0.05). In our study, unlike the work of Patel et al. ${ }^{8}$, $\mathrm{CHO}$ cells are exposed to PM for 30 min and comet assay is performed by using FPG enzyme additionally. According to the results of our study, after 30 min application of PM in 1-10000 $\mathrm{mM}$ concentrations and following $50 \mathrm{mM} \mathrm{H}_{2} \mathrm{O}_{2}$ application for 5 min, the oxidative DNA damage which is formed in $\mathrm{CHO}$ cells can be repaired by FPG enzyme.

\section{CONCLUSION}

The data in the literature combined with our results show that commonly used dinitroaniline herbicides PM induced DNA damage in 1-10000 $\mathrm{mM}$ concentration in $\mathrm{CHO}$ cells can be detected by comet assay. Patel et al. ${ }^{8}$ also conclude that PM may possess clastogenic effects such as some compounds having the same chemical structure of dinitroaniline herbicides. In this study, $\mathrm{CHO}$ cells are incubated with PM for 30 min. For more information about DNA damaging effects of PM, it will be useful to perform similar studies using longer incubation periods more than $30 \mathrm{~min}$. In further studies, to refine the 
data obtained in our study in the concentration range from 1 to $10000 \mathrm{mM}$ and to be informed about the possible effects on close to human exposure concentrations, the DNA damage should be detected in concentrations below $10 \mathrm{mM}$. In addition, chromosomal aberration studies must be carried out for the detection of claimed clastogenic effects of PM.

Conflict of Interest: No conflict of interest was declared by the authors.

\section{REFERENCES}

1. Kegley S, Hill B, Orme S, Pendimethalin. PAN Pesticide Database, Pesticide Action Network, North America, San Francisco, CA, 2007, Available via 〈http://www.pesticideinfo.org〉

2. Clarke J, Wynn S, Twinning S, Berry P, Cook S, Ellis S, Gladders P. Pesticide availability for cereals and oilseeds following revision of Directive 91/414/EEC, effects of losses and new research priorities, In: HGCA Research Review Nr 70. 2009.

3. Strandberg M, Scott-Fordsmand JJ. Effects of pendimethalin at lower trophic levels a review. Ecotoxicol Environ Safe. 2004;57:190-201.

4. Venkata Mohan S, Rama Krishna M, Muralikrishna P, Shailaja S, Sarma PN. Solid phase bioremediation of pendimethalin in contaminated soil and evaluation of leaching potential. Bioresour Technol. 2007;98:29052910.

5. US Environmental Protection Agency (US EPA), R.E.D. Facts: Pendimethalin, US EPA, Washington, DC, 1997.

6. Yamano T, Morita S. Effects of pesticides on isolated rat hepatocytes, mitochondria, and microsomes II. Arch Environ Contam Toxicol. 1995;28:1-7.

7. Pan $H$, Sun D, Wang J, Wu D. Using the FRTL-5 cell to screen the thyroxine disrupting effects of the two pesticides-ethylenethiourea and pendimethalin. Wei Sheng Yan Jiu. 2004;33:267-269.

8. Patel S, Bajpayee M, Pandey AK, Parmar D, Dhawan A. In vitro induction of cytotoxicity and DNA strand breaks in $\mathrm{CHO}$ cells exposed to cypermethrin, pendimethalin and dichlorvos. Toxicol In Vitro. 2007;21:1409-1418.

9. Dimitrov BD, Gadeva PG, Benova DK, Bineva MV. Comparative genotoxicity of the herbicides Roundup, Stomp and Reglone in plant and mammalian test systems. Mutagenesis. 2006;21:375-382.

10. Promkaev N, Soontornchainaksaeng P, Jampatong S, Rojanavipart P. Toxicity and genotoxicity of pendimethalin in maize and onion. Kasersart J (Nat Sci). 2010;44:1010-1015.

11. Singh B, Singh K. Microbial degradation of herbicides. Crit Rev Microbiol. 2014;:42:1-17.

12. Hurley PM. Mode of carcinogenic action of pesticides inducing thyroid follicular cell tumors in rodents. Environ Health Perspect. 1998;106:437445.

13. Alavanja MC, Dosemeci M, Samanic C, Lubin J, Lynch CF, Knott C, Barker J, Hoppin JA, Sandler PD, Coble J, Thomas K, Blair A. Pesticides and lung cancer risk in the agricultural health study cohort. Am J Epidemiol. 2004;160:876-885.
14. Hou L, Lee WJ, Rusiecki J, Hoppin JA, Blair A, Bonner MR, Lubin JH, Samanic C, Sandler DP, Dosemeci M, Alavanja MC. Pendimethalin exposure and cancer incidence among pesticide applicators. Epidemiology. 2006;17:302-307.

15. Fairbairn DW, Olive PL, O'Neill KL. The comet assay: a comprehensive review. Mutat Res. 1995;339:37-59.

16. Speit G, Hartmann A. The comet assay (single-cell gel test). A sensitive genotoxicity for the detection of DNA damage and repair. Methods Mol Biol. 1999;113:203-212.

17. Collins AR, Duthie SJ, Dobson VL. Direct enzymic detection of endogenous oxidative base damage in human lymphocyte DNA. Carcinogenesis. 1993;14:1733-1735.

18. Collins AR, Dusinska M, Gedik CM, Stetina R. Oxidative damage to DNA: do we have a reliable biomarker? Environ Health Perspect. 1996;104:465469.

19. Tennant JR. Evaluation of the trypan blue technique for determination of cell viability. Transplantation. 1964;2:685-694.

20. Singh NP, McCoy MT, Tice RR, Schneider EL. A simple technique for quantitation of low levels of DNA damage in individual cells. Exp Cel Res. 1988;175:184-191.

21. Collins AR, Dobson VL, Dusinska M, Kennedy G, Stetina R. The comet assay: what can it really tell us? Mutat Res. 1997;375:183-193.

22. Undeğer U, Başaran A, Degen GH, Başaran N. Antioxidant activities of major thyme ingredients and lack of (oxidative) DNA damage in V79 Chinese hamster lung fibroblast cells at low levels of carvacrol and thymol. Food Chem Tox. 2009;47:2037-2043.

23. Aydın S, Tokaç D, Başaran N, Başaran AA. Effect of epigallocatechin gallate on oxidative DNA damage in human lymphocytes. Turk J Pharm Sci. 2015;12:19-28.

24. Olive PL, Banath JP, Durand RE. Heterogeneity in radiation-induced DNA damage and repair in tumor and normal cells measured using the 'comet' assay. Radiat Res. 1990;122:86-94.

25. Villarini M, Moretti M, Pasquini R, Scassellati-Sforzolini G, Fatigoni C, Marcarelli M, Monarca S, Rodriguez AV. In vitro genotoxic effects of the insecticide deltamethrin in human peripheral blood leukocytes: DNA damage ('comet' assay) in relation to the induction of sister-chromatid exchanges and micronuclei. Toxicology. 1998;130:129-139.

26. Azqueta A, Shaposhnikov S, Collins AR. Detection of oxidised DNA using DNA repair enzymes. In: Dhawan A, Anderson D, eds. The comet assay in toxicology. RSC Publishing; Cambridge; 2009:57-78.

27. Cooke MS, Evans MD, Dizdaroglu M, Lunec J. Oxidative DNA damage: mechanisms, mutation, and disease. FASEB J. 2003;17:1195-1214.

28. Olinski R, Gackowski D, Foksinski M, Rozalski R, Roszkowski K, Jaruga $P$. Oxidative DNA damage: assessment of the role in carcinogenesis, atherosclerosis, and acquired immunodeficiency syndrome. Free Radic Biol Med. 2002;33:192-200.

29. Shen HM Ong C. Detection of oxidative DNA damage in human sperm and its association with sperm function and male infertility. Free Radic Biol Med. 2000;28:529-536.

30. Harman D. Aging: a theory based on free radical and radiation chemistry. J Gerontol. 1956;11:298-300. 